\title{
The Effects of Politically Connected Audit Committees on Audit Fees: Evidence in Malaysia
}

\author{
Nurul Nazlia Jamil \\ Faculty of Economics and Muamalat (FEM) \\ Universiti Sains Islam Malaysia, Nilai, Negeri Sembilan, Malaysia
}

Received: February 22, 2018

Accepted: March 6, 2018

Published: March 14, 2018

doi:10.5296/ifb.v5i1.12815

URL: http://dx.doi.org/10.5296/ifb.v5i1.12815

\begin{abstract}
This study aims to contribute to an understanding of politically connected audit committees on audit fees in an emerging market, using the case of Malaysia. Malaysia offers an interesting and important setting as Malaysian companies are highly concentrated and politically sensitive. In particular, the study seeks to examine the level of political connections represented in the audit committees associated with the level of audit fees incurred by Malaysian public listed companies. For the purpose of this study, a quantitative approach (archival data analysis) has been adopted. Three hypotheses are tested: (1) There is a positive relationship between the proportion of audit committee members who are senior government officers (SGO) and audit fees; (2) There is a positive relationship between the proportions of audit committee members who are politicians and audit fees; (3) There is a positive relationship between audit committee characteristics (independence, size, meeting and financial expertise) and audit fees. The results of the study indicate that politically connected audit committees (identified by members who are either senior government officers or politicians) have a significant association with the incidence of higher audit fees. This suggests that politically connected audit committees are able to capitalize on their connections to influence companies and create direct demand for the auditors to increase their audit effort, as measured by audit fees. One of the issues that emerge from these findings is that companies highly value political connections to obtain external resources given the uncertainties in the business environment. Also, the findings highlight the need for stronger corporate governance to mitigate the higher inherent audit risks in politically connected companies.
\end{abstract}

Keywords: Political connections, Audit committee, Audit fees 


\section{Introduction}

Audit committees are now a common feature of corporate governance in many countries. Widely promoted since the publication of the Cadbury Report (1992), audit committees are now expected, and in some cases required, to exercise oversight over financial reporting and auditing. Research on audit committees suggest that independence, expertise and meeting frequency are important determinants of their effectiveness and that their connections with management and stakeholders can affect their monitoring role. A potentially important aspect that can affect audit committee monitoring behaviour is inclusion of members on audit committees who are politicians or senior government officers. This paper examines the relationship between connected audit committees, i.e. those that have members who are politicians (hereafter ACPOL) or senior government officers (hereafter ACSGO), and audit fees. This study seeks to extend the audit committee literature by examining the effects of connected audit committees on audit pricing. Political connection may affect audit pricing in number of ways. Politically connected firms may be deemed as posing additional risks and auditors thus may exercise greater effort in auditing such clients and reflect the greater effort in their pricing. Similarly, audit committee members who are politicians or senior government officers may be keen to achieve and demonstrate greater assurance in financial reporting by demanding higher auditor effort. Research on the effectiveness connected audit committees is limited. The paper provides evidence on audit committee in relation to how member connections affect their monitoring behaviour.

The examination of the effect of audit committees with members who are politicians or who serve as senior government officers on audit fees is based on data from Malaysia which is an interesting setting characterized by the existence of politically connected firms. This is a result of the introduction of the government's new economic policy as well as the informal ties among firms run by Malay, Chinese and Indian businessman along with the prominent political figures (Gomez \& Jomo, 1997). A unique feature in Malaysia is the close links if many large corporations or conglomerates with the government. Given this special environment, Malaysia provides a setting in which the study can more specifically examine the relationship between connected audit committees and their monitoring behaviour as reflected in audit in audit fees.

When examining governance and audit pricing, it is important to consider the political connection of audit committees. This is particularly important because audit committees have a more direct role in monitoring financial reporting, auditing and risks. To the best of the researcher knowledge, this paper is the first to test the empirical question of whether connected audit committees are associated with greater audit effort, as reflected in audit fees. This paper compliments recent studies on the effectiveness of audit committee in different institutional settings, such as Salleh \& Stewart (2012) and Zaman et al. (2011). Overall, the study find evidence consistent with the view that politicians and senior government officers on audit committees are likely to be concerned about protecting their reputation and undertake greater oversight. Specifically, the study finds a positive and significant relationship between audit committee connections and audit fees suggesting that auditors exert greater effort and this is reflected in audit pricing. 


\section{Literature Review}

\subsection{Governance and Audit Pricing}

Audit demand may be viewed as a function of the set of risks faced by an organisation's individual stakeholders and of the set of control mechanisms available for mitigating these risks (Hay et al., 2008). Because individual decisions about control processes and procedures may shift benefits and costs across groups of stakeholders, the net investment in auditing may increase when multiple stakeholders become involved in corporate governance decisions. For example, the audit cost is more likely to be borne by equity shareholders who may have little say in determining the extent of audit work undertaken (Carcello et al., 2002; Hay et al., 2008). Similarly, Carcello et al. (2002), Abbott et al. (2003) and Fan \& Wong (2005) argue that the demand for stronger corporate governance induces the auditee to seek out better auditing and internal control. Thus, because good governance is valued by the firm's stakeholders, it is more likely to invest more in monitoring which is likely to be reflected in higher audit fees. Hay et al. (2008) suggest that a "demand side" effect may result in a positive relationship between corporate governance and audit fees. (Note 1)

The introduction of corporate governance reforms, such as the US Sarbanes Oxley Act and the UK Corporate Governance Code which has its origins in the Cadbury Report (1992) on financial aspects of corporate governance, have increased the role of audit committees for the oversight of reporting and auditing (Cohen et al., 2013); Salleh \& Stewart, 2012). Indeed, Cohen et al. (2010) find post-SOX there has been a positive shift in the seriousness audit committee members bring to their monitoring role. Prior research finds that board and audit committee characteristics affect audit fees (see Abbott \& Parker 2000; Beasley et al., 2000; Carcello et al., 2002; Raghunandan et al., 2001). Audit committees that are independent, have a financial expert and are active are associated with greater demand for audit effort and audit fees (Goodwin-Stewart \& Kent 2006; Zaman et al., 2011). Boards and audit committees may also seek to protect their reputational capital and avoid legal liability (Gilson, 1990) by demanding higher audit effort. More specifically, Hay et al. (2008) suggest that audit committees and boards of directors have an investment in reputation capital and do not themselves pay for improved internal controls and greater external auditing. To protect them from damage to their reputation or personal liability that might arise from misstatements in financial reports they are likely to demand greater audit effort and pay higher audit fees. Additionally, from a demand side perspective, if audit committees complement the work performed by external auditors their monitoring may result in auditors expanding the scope of the audit and exerting greater effort which is likely to be reflected in higher audit fees.

Prior literature on audit committees generally suggests that audit committees that have financial expertise, are active and have independent directors tend to engage in greater oversight of financial reporting and auditing (see for example Bedard \& Gendron, 2010; Ghafran \& O'Sullivan, 2012 for literature reviews). There is also evidence, for instance, that the status and standing of audit committee members, audit committee connections and networks also affect their monitoring role (Turley \& Zaman, 2007; Bruynslees \& Cardinaels, 2013; Cohen et al., 2013; Hossain et al., 2016). These studies suggest that audit committee 
members' background and connections can affect their independence and monitoring. Indeed, when audit committee members are connected it may lead to the audit committee being passive and offering little or no monitoring or depending on the nature of the connection greater there may be greater oversight and monitoring (Turley \& Zaman, 2007; Bedard \& Gendron, 2010, Bruynslees \& Cardianels, 2013). An important dimension that can also have an effect on monitoring is the presence of politicians and senior government officers on audit committees.

\section{Research Methodology}

\subsection{Model}

The study uses the following model to test the two hypotheses discussed in the previous section:

\section{$L N A F=\beta 0+\beta 1$ ACCONNECTION $+\beta 2$ ACINDEP $+\beta 3$ ACSIZE $+\beta 4$ ACMEETING + B5ACEXPERT + B6BIG4 + B7OPINION + B8BIG4 + B9YEAR-END + ß10LOGNAS $+\beta 11$ LOGASSETS $+\beta 12$ LOGSUBS $+\beta 13 \mathrm{INV}+\beta 14 \mathrm{REC}+$ B15LEVERAGE $+\varepsilon$}

The dependent variable is the natural log of audit fees. For audit committee connections (ACCONNECTED) the study use two measures: ACPOL which is the proportion of audit committee members who are politicians and ACSGO which is the proportion of audit committee members who are senior government officers. The names of senior officers and politicians on audit committees was collected manually from annual reports and company websites and reconciled manually with the names of the politicians listed in the election and parliament websites with the information given in the annual reports. The study defined political connections by identifying the members of audit committees who are senior government officers or politicians, based on the "board profile" of the members of the board from the annual reports published by the companies and from the election or parliament websites, which are all publicly available. Following earlier literature (Boubakri et al., 2012; Chaney et al., 2011;Duchin and Sosyura, 2012;Faccio et al., 2006; Goldman et al., 2008), the study consider the presence of politicians or senior government officers on firms' audit committees as a proxy for connected audit committees. (Note 2) Following prior literature, the study include audit committee variables, i.e., ACSIZE, ACINDEP, ACMEET, ACEXPERT, in the audit fee model. Additionally, based on prior audit fee studies the study also control for firm size, total debt, number of subsidiaries, ratio of receivables to total assets, and ratio of inventory to total assets and opinion (Simunic et al., 2008; Craswell et al., 1995; Hay et al., 2006; Tsui et al., 2001).

\subsection{Data and Sample}

Data on the composition of audit committees was manually collected from 2012 annual reports and financial data was obtained from Datastream. The sample consists of 810 companies listed on the Main Board of Bursa Malaysia in 2012. The study excludes 51 firms that operate in the financial sector due to their unique characteristics and specific regulations which may affect the results. The sample size has been reduced by a further 13 firms as a 


\section{Macrothink \\ International Finance and Banking \\ ISSN 2374-2089 \\ 2018, Vol. 5, No. 1}

result of missing information in DataStream and annual reports. After these eliminations, the remaining sample is 746 firms.

\section{Results}

\subsection{Descriptive Statistic}

Table 1 provides descriptive statistics for the dependent and independent variables. In general, the distributions are similar to previous studies undertaken in the Malaysian market (Eichenseher, 1995; Haniffa et al., 2006a). Some of the results are also comparable with international settings, such as the US (Abbott et al. 2003), the UK (Zaman et al., 2011), Australia (Davidson et al., 2005) and Taiwan (Chi \& Huang 2005). From the descriptive statistics reported in Table 1, the study find the average log audit fees is 12.234 (RM445,000) and ranges from 8.006 (RM3, 000) to 17.223 (RM30.2 million).

Turning to the variable of interest in the study, the connection of audit committee members which is a particular feature of the institutional setting in Malaysia, the study find the proportion of audit committee members who are senior government officers (ACSGO) is $0.222(22.2 \%)$ and the proportion of audit committee members who are politicians is 0.088 $(8.8 \%)$. On average $77.1 \%$ of audit committee members are independent. The mean size of audit committees is 3.61 members, which is above the recommended minimum of three for firms listed in Bursa Malaysia (2011). The mean percentage of audit committee members with accounting and financial expertise is $66.1 \%$ which is slightly higher than the $60 \%$ that Krishnan \& Visvanathan (2009) report for US companies but relatively similar to $70 \%$ reported by Zaman et al. (2011) for the UK. With regards to audit committee meetings, the number of meeting held in the year ranges from 3 to 10 with a mean of 5.48 meetings per year which is above the recommended minimum of four meetings a year (MCCG, 2009, para 2.6.2) 


\section{NI Macrothink}

International Finance and Banking

ISSN 2374-2089

2018, Vol. 5, No. 1

Table 1. Descriptive statistics

\begin{tabular}{|l|c|c|c|c|c|}
\hline & Mean & Median & Max & Min & SD \\
\hline Panel A: Audit Fees & & & & & \\
\hline LOGAF & 12.234 & 12.139 & 17.223 & 8.006 & 1.008 \\
\hline LNAF & 6.901 & 9.210 & 16.082 & 0 & 5.115 \\
\hline Panel B: AC Connections & & & & & \\
\hline ACSGO (P) & 0.222 & 0.250 & 1 & 0 & 0.239 \\
\hline ACPOL (P) & 0.088 & 0 & 1 & 0 & 0.175 \\
\hline Panel C: Audit Committee & & & & & \\
\hline ACINDEP & 0.771 & 0.800 & 1 & 0.250 & 0.277 \\
\hline ACSIZE & 3.610 & 3 & 8 & 3 & 0.742 \\
\hline ACMEETING & 5.480 & 5 & 10 & 3 & 1.547 \\
\hline ACEXPERT & 0.661 & 0.750 & 1 & 0.167 & 0.301 \\
\hline Panel D: Firm measures & & & & & \\
\hline BIG 4 & 0.700 & 1 & 1 & 0 & 0.459 \\
\hline AUDITOPINION & 0.080 & 0 & 1 & 0 & 0.266 \\
\hline AUDITTENURE & 5.050 & 5 & 9 & 2 & 1.744 \\
\hline YEAR END & 0.570 & 1 & 1 & 0 & 0.495 \\
\hline SUBSIDIARIES & 14.520 & 10 & 378 & 1 & 18.822 \\
\hline LOGSUB & 2.300 & 2 & 6 & 0 & 0.909 \\
\hline LOGASSETS & 19.841 & 19.633 & 24.907 & 15.470 & 1.428 \\
\hline RATIORECEIVABLES & 0.141 & 0.107 & 0.650 & 0.000 & 0.137 \\
\hline RATIOINVENTORY & 0.080 & 0.060 & 0.400 & 0.000 & 0.101 \\
\hline LEVERAGE & 0.260 & 0.189 & 0.701 & 0 & 0.240 \\
\hline Panel D: Ringgit Malaysia measures & & & & & \\
\hline AF ('000) & 445 & 187 & 30,200 & 3 & 1,490 \\
\hline NAS ('000) & 116 & 10 & 9,643 & 0 & 595 \\
\hline TASSETS ('000) & $1,717,091$ & 335,991 & $65,615,298$ & 5,231 & $5,667,399$ \\
\hline RECEIVABLES('000) & 39,822 & 33,205 & $1,968,458$ & 156 & 170,021 \\
\hline INVENTORY ('000) & 139,676 & 28,940 & $7,256,200$ & 575 & 503,890 \\
\hline
\end{tabular}

Notes. $\mathrm{LOGAF}=$ natural $\log$ total audit fees; $\mathrm{LOGNAS}=$ natural $\log$ of amount non audit services paid to the external auditors; $\mathrm{ACSGO}=$ proportion of audit committee who is senior government officer; $\mathrm{ACPOL}=$ proportion of audit committee who is politician; GOVSHARE= percentage of shares owned by the government; $\mathrm{ACINDEP}=$ proportion of independent $\mathrm{AC}$ members to size of $\mathrm{AC}$; $\mathrm{ACSIZE}=$ number of $\mathrm{AC}$ member; ACMEET= number of meeting in an accounting year; ACEXPERT= pe proportion of audit committee who has financial professional qualifications (MIA,ACCA,CIMA and other accounting professional qualifications); BIG4= An indicator variable 1 for BIG 4 auditor and 0 otherwise; AUDITOPIN= 1 if modified opinion, 0 otherwise; AUDITENURE $=$ duration of tenure for auditors; YEAREND= financial year end on $31^{\text {st }}$ December $=1,0$ otherwise; SUBSIDIARIES $=$ number of subsidiaries; LOGSUB $=\log$ transformation of subsidiaries; LOGFIRM'S SIZE= Log of total asset; INVENTORY= ratio of inventory to total assets; RECEIVABLES= ratio of receivables to total assets; $\mathrm{LEV}=$ long term debt to total assets. 


\subsection{Main Regression Results}

Table 2 reports the multiple regression results testing the hypotheses of the association between connected audit committees, denoted by ACSGO and ACPOL, and audit fees. The study finds the model with ACSGO as the proxy for audit committee connection has explanatory power, with adjusted R-square of $44.5 \%$ whereas the model with ACPOL as a proxy for audit committee connection has adjusted R-square of 44.4\%. Both models are significant $(\mathrm{p}<0.000)$.

Turning to the variables of interest, ACSGO and ACPOL have both positive and significant relationship with LOGAF. The results show that ACSGO is significant with a positive coefficient of 0.136 (t-stats $=3.216$ ), and ACPOL is also significant with a coefficient of 0.139 (t-stats $=3.314)$. Both ACSGO and ACPOL are significant at the one per cent level with the natural logarithm of audit fees, LOGAF. The results in Table 3 provide support for the two hypotheses and are consistent with the view that audit committee members who are politicians or audit committee members who are senior government officers have a positive association with audit fees.

The study also finds that the log of audit fees (LOGAF) has a positive and significant association with audit committee senior government officers (ACSGO), audit committee politicians (ACPOL), audit committee independence (ACINDEP), audit committee size (ACSIZE), logarithm of non-audit services (LOGNAS), logarithm of total assets (LOGASSETS), logarithm of subsidiaries (LOGSUB), ratio of receivables to total assets (RATIORECEIVABLES) and ratio of total debt to total asset (LEVERAGE). On the other hand, the study finds a negative relationship between audit fees and audit committee meetings (ACMEETING), auditor opinion (OPINION), auditor tenure (TENURE) and year end (YEAREND).

It is noteworthy that the study finds audit committee connection, whether denoted by ACSGO or by ACPOL, is positive and significant in addition to audit committee variables that have been subject of prior audit fees studies. In particular, the study also finds that both ACIND and ACSIZE have a positive and significant association with audit fees. In previous studies conducted in Malaysia, Haniffa et al. (2006b) and Bliss et al. (2011) did not find any such direct relationship. However, Bursa Malaysia has raised the bar for the requirement of audit committee independence through Paragraph 15.10 of the listing requirements, which states that the audit committee should comprise non-executive directors with a majority being independent. This result suggests that the requirement has had a strong impact on audit pricing. The finding here corresponds with observations in earlier studies by Abbott et al. (2003) and Carcello et al. (2002) that more independent audit committees demand a higher quality audit service which is measured using audit fees as a proxy. ACEXPERT has a positive but insignificant relationship with the natural logarithm of audit fees. However, ACMEET has a negative relationship with LOGAF which might be due to the number of meetings not indicating how many issues are being discussed in terms of audit planning and audit scope. (Note 4)

Overall, the audit fee model appears to be well specified and the result show that audit 
committee connection, denoted by ACSGO and ACPOL, has a positive and significant association with audit fees. The results are consistent with the view that behavior of politically connected directors influences decision making in firms (Chizema et al., 2015).

Table 3. ACSGO and ACPOL effect on audit fees

\begin{tabular}{|c|c|c|}
\hline Variables & ACSGO & ACPOL \\
\hline & 3.292 & 3.206 \\
\hline Constant & $(5.153)^{* * *}$ & $(4.955)^{* * *}$ \\
\hline \multirow{2}{*}{ ACSGO } & 0.136 & \\
\hline & $(3.216)^{* * *}$ & \\
\hline \multirow{2}{*}{ ACPOL } & & 0.139 \\
\hline & & $(3.314)^{* * *}$ \\
\hline \multirow{2}{*}{ ACINDEP } & 0.115 & 0.117 \\
\hline & $(3.419)^{* * *}$ & $(3.470)^{* * *}$ \\
\hline \multirow{2}{*}{ ACSIZE } & 0.128 & 0.122 \\
\hline & $(4.989)^{* * *}$ & $(4.778)^{* * *}$ \\
\hline \multirow{2}{*}{ ACMEETING } & -0.033 & -0.034 \\
\hline & $(-1.157)$ & $(-1.192)$ \\
\hline \multirow{2}{*}{ ACEXPERT } & 0.011 & 0.008 \\
\hline & $(0.299)$ & $(0.209)$ \\
\hline \multirow{2}{*}{ BIG 4} & 0.007 & 0.006 \\
\hline & $(0.256)$ & $(0.224)$ \\
\hline \multirow{2}{*}{ OPINION } & -0.032 & -0.033 \\
\hline & $(-1.136)$ & $(-1.187)$ \\
\hline \multirow{2}{*}{ AUDIT TENURE } & -0.016 & -0.015 \\
\hline & $(-0.524)$ & $(-0.485)$ \\
\hline \multirow{2}{*}{ YEAR END } & -0.025 & -0.025 \\
\hline & $(-0.885)$ & $(-0.887)$ \\
\hline \multirow{2}{*}{ LOGNAS } & 0.114 & 0.114 \\
\hline & $(3.752)^{* * *}$ & $(3.750) * * *$ \\
\hline \multirow{2}{*}{ LOGASSETS } & 0.578 & 0.589 \\
\hline & $(12.894)^{* * *}$ & $(13.282)^{* * *}$ \\
\hline \multirow{2}{*}{ LOGSUB } & 0.188 & 0.185 \\
\hline & $(5.953)^{* * *}$ & $(5.863) * * *$ \\
\hline \multirow{2}{*}{ RATIONINVENT } & 0.037 & 0.038 \\
\hline & $(1.316)$ & $(1.340)$ \\
\hline \multirow{2}{*}{ RATIOREC } & 0.132 & 0.131 \\
\hline & $(3.504)^{* * *}$ & $(3.476)^{* * *}$ \\
\hline \multirow{2}{*}{ LEVERAGE } & 0.107 & 0.106 \\
\hline & $(3.232)^{* * *}$ & $(3.210)^{* * *}$ \\
\hline $\mathrm{N}$ & 746 & 746 \\
\hline $\mathrm{R}$ & 0.675 & 0.674 \\
\hline $\mathrm{R}^{2}$ & 0.456 & 0.455 \\
\hline Adjusted $\mathrm{R}^{2}$ & 0.445 & 0.444 \\
\hline F-stat & 40.765 & 40.597 \\
\hline $\mathrm{P}$-value & 0 & 0 \\
\hline
\end{tabular}

Notes. Correlation is significant at the $0.01(1 \%)^{* * *}, 0.05(5 \%)^{* *}, 0.10(10 \%)^{*}$ level. Variables are as defined in the note in Table 1. 


\section{Discussion and Conclusion}

This paper examined the relationship between connected audit committees and monitoring. Specifically, the study extends the literature on audit committees by exploring the association between audit committee members who are politicians or senior government officers and audit fees. As additional test the study also explored if connected audit committees are associated with greater monitoring using discretionary accruals as a proxy. Overall, the study find evidence consistent with the view that politicians and senior government officers on audit committees are likely to be concerned about protecting their reputation and undertake greater oversight. Specifically, the study finds a positive and significant relationship between audit committee connections and audit fees suggesting that auditors exert greater effort and this is reflected in audit pricing. Similarly, the study also finds a negative relationship between audit committee connection (whether denoted by ACSGO or ACPOL) and discretionary accruals. The overall findings remain unchanged when the study control for industry and board of director characteristics.

Although the paper is a first to explore the monitoring behavior of audit committees with politicians and senior government officers, nonetheless it is an exploratory study and has a number of limitations. Further research is needed to better understand the influence of connected audit committee members, how they interact with external auditors and company management to improve the quality of financial reporting and auditing. While the evidence is based on the Malaysian setting, future research can contribute to understanding how audit committees with politicians and senior government officers effect monitoring in different institutional settings.

\section{References}

Abbott, L. J., \& Parker, S. (2000). Auditor Selection and Audit Committee Characteristics. AUDITING: A Journal of Practice \& Theory, 19(2), 47-66. https://doi.org/10.2308/aud.2000.19.2.47

Abbott, L. J., Parker, S., Peters, G. F., \& Raghunandan, K. (2003). The Association between Audit Committee Characteristics and Audit Fees. AUDITING: A Journal of Practice \& Theory, 22(2), 17-32. https://doi.org/10.2308/aud.2003.22.2.17

Abbott, L. J., Parker, S., Peters, G. F., \& Raghunandan, K. (2003). An Empirical Investigation of Audit Fees, Nonaudit Fees, and Audit Committees. Contemporary Accounting Research, 20(2), 215-234. https://doi.org/10.1506/8YP9-P27G-5NW5-DJKK

Beasley, M. S., Carcello, J. V., Hermanson, D. R., \& Lapides, P. D. (2000). Fraudulent Financial Reporting: Consideration of Industry Traits and Corporate Governance Mechanisms. Accounting Horizons, 441-454. https://doi.org/10.2308/acch.2000.14.4.441

Bliss, M. A. (2011). Does CEO duality constrain board independence? Some evidence from audit pricing. Accounting \& Finance, 51(2), 361-380. https://doi.org/10.1111/j.1467-629X.2010.00360.x 
Boubakri, N., Guedhami, O., Mishra, D. \& Saffar, W. (2012). Political connections and the cost of equity capital. Journal of Corporate Finance, 18(3), 541-559. https://doi.org/10.1016/j.jcorpfin.2012.02.005

Bruynseels, L., \& Cardinaels, E. (2013). The audit committee: Management watchdog or personal friend of the CEO?. The Accounting Review, 89(1), 113-145. https://doi.org/10.2308/accr-50601

Carcello, J. V., Hermanson, D. R., Neal, T. L., \& Riley, R. A. (2002). Board Characteristics and Audit Fees. Contemporary Accounting Research, 19(3), 365-384. https://doi.org/10.1506/CHWK-GMQ0-MLKE-K03V

Chaney, P. K., Faccio, M., \& Parsley, D. (2011). The quality of accounting information in politically connected firms. Journal of Accounting and Economics, 51(1-2), 58-76. https://doi.org/10.1016/j.jacceco.2010.07.003

Chi, W., \& Huang, H. (2005). Discretionary accruals, audit-firm tenure and audit-partner tenure: Empirical evidence from Taiwan. Journal of Contemporary Accounting \& Economics, 1(1), 65-92. https://doi.org/10.1016/S1815-5669(10)70003-5

Chizema, A., Liu, X., Lu, J., \& Gao, L. (2015). Politically connected boards and top executive pay in Chinese listed firms. Strategic Management Journal, 36(6), 890-906. https://doi.org/10.1002/smj.2253

Cohen, J., Krishnamoorthy, G., \& Wright, A. (2010). Corporate governance in the post-Sarbanes-Oxley era: Auditors' experiences. Contemporary Accounting Research, 27(3), 751-786. https://doi.org/10.1111/j.1911-3846.2010.01026.x

Cohen, J. R., Colleen Hayes, C., Krishnamoorthy, G., Monroe, G. S., \& Wright, A. (2013) The Effectiveness of SOX Regulation: An Interview Study of Corporate Directors. Behavioral Research in Accounting, 25(1), 61-87. https://doi.org/10.2308/bria-50245

Craswell, A. T., Francis, J. R., \& Taylor, S. L. (1995). Auditor brand name reputations and industry specializations. Journal of Accounting and Economics, 20(3), 297-322. https://doi.org/10.1016/0165-4101(95)00403-3

Davidson, R., Goodwin-Stewart, J., \& Kent, P. (2005). Internal governance structures and earnings management. Accounting and Finance, 45(2), 241-267. https://doi.org/10.1111/j.1467-629x.2004.00132.x

Duchin, R., \& Sosyura, D. (2012). The politics of government investment. Journal of Financial Economics, 106(1), 24-48. https://doi.org/10.1016/j.jfineco.2012.04.009

Faccio, M., Masulis, R. W., \& McConnell, J. (2006). Political connections and corporate bailouts. The Journal of Finance, 61(6), 2597-2635. https://doi.org/10.1111/j.1540-6261.2006.01000.x

Fan, J. P. H., \& Wong, T. J. (2005). Do External Auditors Perform a Corporate Governance Role in Emerging Markets? Evidence from East Asia. Journal of Accounting Research, 
43(1), 35-72. https://doi.org/10.1111/j.1475-679x.2004.00162.x

Gilson, S. C. (1990). Bankruptcy, boards, banks, and blockholders: Evidence on changes in corporate ownership and control when firms default. Journal of Financial Economics, 27(2), 355-387. https://doi.org/10.1016/0304-405X(90)90060-D

Goldman, E., Rocholl, J., \& So, J. (2008). Do Politically Connected Boards Affect Firm Value? Review of Financial Studies, 22(6), 2331-2360. https://doi.org/10.1093/rfs/hhn088

Gomez, E. T., \& Jomo, K. S. (1997). Malaysia's Political Economy: Politics. Patronage and Profits.

Goodwin-Stewart, J., \& Kent, P. (2006). Relation between external audit fees, audit committee characteristics and internal audit. Accounting and Finance, 46(3), 387-404. https://doi.org/10.1111/j.1467-629X.2006.00174.X

Haniffa, R., Yatim, P., Kent, P., \& Clarkson, P. (2006b). Governance structures, ethnicity, and audit fees of Malaysian listed firms. Managerial Auditing Journal, 21(7), 757-782. https://doi.org/10.1108/02686900610680530

Hay, D., Knechel, W. R., \& Ling, H. (2008). Evidence on the impact of internal control and corporate governance on audit fees. International Journal of Auditing, 12(1), 9-24. https://doi.org/10.1111/j.1099-1123.2008.00367.x

Hay, D. C., Knechel, W. R., \& Wong, N. (2006). Audit Fees: A Meta-analysis of the Effect of Supply and Demand Attributes. Contemporary accounting research, 23(1), 141-191. https://doi.org/10.1506/4XR4-KT5V-E8CN-91GX

Hossain, S., Monroe, G. S., Wilson, M., \& Jubb, C. (2016) The Effect of Networked Clients' Economic Importance on Audit Quality. Auditing: A Journal of Practice \& Theory, In-Press.

Krishnan, G., \& Visvanathan, G. (2009). Do auditors price audit committee's expertise? The case of accounting versus nonaccounting financial experts. Journal of Accounting, Auditing \& Finance, 24(1), 115-144. https://doi.org/10.1177/0148558X0902400107

Raghunandan, K., Rama, D. V., \& Read, W. J. (2001). Audit committee composition,"gray directors," and interaction with internal auditing. Accounting Horizons, 15(2), 105-118. https://doi.org/10.2308/acch.2001.15.2.105

Salleh, Z., \& Stewart, J. (2012). The role of the audit committee in resolving auditor-client disagreements: a Malaysian study. Accounting, Auditing \& Accountability Journal, 25(8), 1340-1372. https://doi.org/10.1108/09513571211275506

Simunic, D. A., Liu, X., Kim, J. B., \& Choi, J. H. (2008). Audit Pricing, Legal Liability Regimes, and Big 4 Premiums: Theory and Cross-country Evidence. Contemporary Accounting Research, 25(1), 55-99. https://doi.org/10.1506/car.25.1.2

Tsui, J. S., Jaggi, B., \& Gul, F. A. (2001). CEO domination, growth opportunities, and their 
impact on audit fees. Journal of Accounting, Auditing \& Finance, 16(3), 189-208. https://doi.org/10.1177/0148558X0101600303

Turley, S., \& Zaman, M. (2007). Audit committee process: informal processes and behavioural effects. Accounting, Auditing and Accountability Journal, 20(5), 765-788. https://doi.org/10.1108/09513570710779036

Zaman, M., Hudaib, M. \& Haniffa, R. (2011). Corporate Governance Quality, Audit Fees and Non-Audit Services Fees. Journal of Business Finance \& Accounting, 38(1-2), 165-197. https://doi.org/10.1111/j.1468-5957.2010.02224.x

\section{Notes.}

Note 1. DeFond \& Zhang (2014) in their review of archival auditing research note that "A distinguishing feature of audit fees is that they are the outcome of both supply and demand factors. Auditors cannot unilaterally charge higher fees for additional effort unless there is a corresponding increase in client demand for the additional effort. As a result, audit fees are used in both demand and supply studies. For example, in demand studies, audit fees are often used to test whether audit committee competencies are associated with audit quality."

Note 2. The study adapt Faccio et al. (2006) in measuring connected audit committees. They consider a firm politically connected if "at least one of its large shareholders (anyone controlling at least $10 \%$ of voting shares) or one of its top officers (CEO, president, vice president, chairman, or secretary) is a member of parliament, a minister, or is closely related to a top politician or party." In contrast to them, our focus on the connection of audit committee members because of their in monitoring financial reporting and auditing.

Note 3. The study follow the definition of financial expertise provided by Bursa Malaysia, i.e., an audit committee member is deemed to be a financial expert if that member has: (a) accounting expertise from work experience as a certified public accountant, auditor, chief financial officer, financial controller or accounting officer; (b) financial expertise from work experience as an investment banker, financial analyst or any other financial management role; or (c) supervisory expertise from supervising the preparation of financial statements (chief executive officer or company president).

Note 4. The insignificant finding for this variable contradicts the findings of Abbott et al. (2003) but is relatively similar to those of Carcello et al. (2002). The mixed findings may be due to variation in the nature of the sample selections. Carcello et al. (2002) examine a sample of Fortune 1000 firms which basically contains larger firms than are found in the sample population examined by (Abbott et al., 2003). 


\section{Macrothink}

\section{Copyrights}

Copyright for this article is retained by the author(s), with first publication rights granted to the journal.

This is an open-access article distributed under the terms and conditions of the Creative Commons Attribution license (http://creativecommons.org/licenses/by/4.0/) 